Arab World English Journal (AWEJ) Volume 12. Number4 December 2021

DOI: https://dx.doi.org/10.24093/awej/vol12no4.31

Pp. 476-486

\title{
Assessment of Flipped Learning as an Innovative Method of Teaching English: A Case Study
}

\section{Natalia Ivanytska}

Department of Foreign Philology and Translation, Vinnytsia Institute of Trade and Economics of Kyiv

National University of Trade and Economics, Vinnytsia, Ukraine

\section{Larysa Dovhan}

Department of Foreign Philology and Translation, Vinnytsia Institute of Trade and Economics of Kyiv

National University of Trade and Economics, Vinnytsia, Ukraine

\section{Nataliia Tymoshchuk}

Department of Foreign Philology and Translation, Vinnytsia Institute of Trade and Economics of Kyiv

National University of Trade and Economics, Vinnytsia, Ukraine

\section{Olga Osaulchyk}

Department of Foreign Philology and Translation, Vinnytsia Institute of Trade and Economics of Kyiv

National University of Trade and Economics, Vinnytsia, Ukraine

Corresponding Author: aulolga55@gmail.com

\section{Nataliia Havryliuk}

Department of Foreign Philology and Translation, Vinnytsia Institute of Trade and Economics of Kyiv National University of Trade and Economics, Vinnytsia, Ukraine

Received: 9/20/2021

Accepted: 12/1/2021

Published:12/15/2021

\section{Abstract}

The article aims to assess the efficiency of flipped learning as one of the most up-to-date methods when teaching English for the EFL students in Ukraine. The significance of the study bases on the necessity to implement advanced teaching practices during the COVID-19 pandemic since online learning requires constructive changes in the traditional system of education. It is necessary to shift from the direct knowledge transfer to searching and cognition of new information by students, to change the teacher's role to being 'a facilitator' and organizer of various academic activities. The article outlines the main characteristics of flipped learning, including flexibility, individualization, differentiation, and opportunities for students to learn at any place or time. The contribution of this research is to estimate new experiences of University students due to flipped learning implementation. It was achieved due to analyzing responses to the survey-based questionnaire of 48 learners and 23 teachers of the Department of Foreign Philology and Translation of Vinnytsia Institute of Trade and Economics of Kyiv National University of Trade and Economics, evaluation of students' performance, attendance, and attitude to the study. In order to verify results of the research, a descriptive statistical and analytical method was applied. The study results reveal that implementation of flipped learning made the educational process more effective and innovative as it improved students' progress in language learning performance, increased their motivation and involvement, and made them more interested in learning English.

Keywords: assessment, effective implementation, facilitator of the learning process, flipped learning, innovative teaching method, Learning Management System, Ukraine's EFL students

Cite as: Ivanytska, N., Dovhan, 1., Tymoshchuk, N. , Osaulchyk, O.,\& Havryliuk, N. (2021). Assessment of Flipped Learning as an Innovative Method of Teaching English: A Case Study. Arab World English Journal, 12 (4) 476-486. DOI: https://dx.doi.org/10.24093/awej/vol12no4.31 


\section{Introduction}

Nowadays, the system of higher education in Ukraine is experiencing some constructive changes since its traditional model does not meet the current needs of society. The COVID-19 pandemic has caused the transfer to online learning. In the current conditions, the teacher is becoming a facilitator of the educational process. Transformations in the educational process organization become possible due to the implementation of flipped learning as a teaching method that increases the satisfaction of students with the results achieved (Abdullah, Hussin, \& Kemboja, 2021), enhancing learners' anxiety in English speaking performance (Thoo, Hang, Lee, \& Tan, 2021).

According to the flipped classroom model, the students have to search for new information and learn new materials before the classroom activities using literature sources, video and audio resources provided by the teacher on the particular topic. Thus, classroom activities are devoted to the formation of practical speaking, reading, and writing skills. Within flipped learning, there can be distinguished 'three roles of lecturer in the learnings process; as a facilitator, an instructor and a resource. While the roles of the learners were as recipients and as partners' (Mahalli, Nurkamto, Mujiyanto, \& Yuliasri, 2019, p. 26). One of the benefits of this model is 'its attractiveness for people with different learning styles' (Hamdani, 2019, p. 13). As a result, students get more motivated, responsible, active, and independent.

There are quite the opposite views and researches proving the flipped learning method is not quite good and cannot substitute the traditional approach. The students and the staff preferred a lecture-based approach rather than the flipped classrooms. Although the students expressed negative attitudes toward the use of flipped classrooms, they improved their learning, and communication skills (Santikarn \& Wichadee, 2018).

Contradictory research results have forced us to set the following research aim: to assess the effectiveness of flipped learning in Ukraine's Universities when teaching EFL students. The significance of this study bases on the urgent need to find new teaching practices that can be effective within online learning.

The following research questions guide this study: 1. Are the teachers familiar with the flipped learning method and ready to implement it? 2. What barriers do the teachers have when implementing flipped learning? 3. Can the flipped learning method improve students' learning performance and motivation, making them more involved and interested in the educational process? 4. What is the attitude of students towards flipped learning? 5. Can flipped learning be effectively implemented using the online platform MOODLE?

\section{Literature Review}

The flipped learning method has been broadly investigated and interpreted since 2012. In 2014, there was MEF University in Turkey founded, and today its educational process is based mainly on flipped learning principles. The universities implementing the flipped learning method include the world's leading universities such as Stanford, Harvard, and many other universities of the USA, the University of Edinburgh, the University of Western Australia and the University of Adelaide, Taiwan University of Science and Technology, and others. This way, the flipped classrooms have become rather popular in higher education. It involves assigning students to 
work through the primary content of a course on their own time, often by watching a recorded lecture or completing a guided reading instead of listening to a traditional in-person lecture. It frees up class time for active problem-solving, demonstrations, experiments, discussions, etc. (Saitta, Morrison, Waldrop, \& Bowdon, 2016). Thus, the flipped classrooms serve the principles of individualized learning, student-oriented instruction, and constructivism, i.e., students perform lots of training activities promoting more meaningful education (Rajesh, 2015). The flipped classroom model is adaptable to the teacher's style, methods, and circumstances (Bergmann, \& Sams, 2012).

There are lots of studies on the effectiveness of flipped learning in teaching English as a foreign language. Basal (2015) implemented the flipped classroom method in an English language class to provide the perceptions of prospective English language teachers towards its application at a State University in Turkey. According to Basal (2015), a successful flipped classroom involves more than just delivering the lectures to students via video outside the class: the time spent in class should be more critical and devoted to understanding, discussing, and investigating, turning the classroom into the place of active learning. Thus, it offers 'several benefits: free classroom time, opportunities for personalized learning, opportunities for more student-oriented learning, a continuous connection between students and teachers, increased motivation of students, a learning environment full of familiar tools, and variety in lecture content attuned to different learning styles' (Basal, 2015, p. 33-34).

Some scientists (Al-Harbi \& Alshumaimeri, 2016; Bane, 2014; Bezzazi, 2019; Thaichay \& Sitthitikul, 2016) have researched the effectiveness of flipped classroom application in grammar teaching. They concluded that this method is vital in enhancing students' grammar performances and emphasizing students' autonomous study. As for flipped writing courses, Yu and Wang (2016) have conducted a survey on undergraduate English writing course students of Business. Scientists (Afrilyasanti et al., 2017) have concluded the method helped students to improve their writing skills. The scientists have also proved that implementing flipped classroom instruction in the EFL university classrooms improves paragraph writing skills of students' (Chatta \& Haque, 2020, p. 228). Similarly, flipping a speaking course brings about better students' academic achievements in verbal activity and increases their level of engagement in the communication process (Choe \& Seong, 2016; Li \& Zhang, 2016; Xin-Yue, 2016; Wu, ChenHsieh \& Yang, 2017; Qader \& Arslan, 2019; Abdullah, Hussin \& Ismail, 2019).

The growing popularity of flipped learning, e-learning, blended or hybrid education is mainly due to the inefficiency of the existing traditional model (Abdullah et al., 2021; Konoplianyk \& Melnykova, 2019). Despite the apparent advantages of foreign language teachers' use of the method of flipped learning, there are several problematic issues both for teachers and students. As for the teachers, they include the high complexity of preparing elearning materials, the need for thorough preparation of tasks and criteria for assessment. As for the students, they involve low motivation, self-motivation, and readiness to independent work. It is obvious the transfer to the model of flipped learning cannot be rapid and requires the adaptation period of time. Considering all advantages and disadvantages mentioned, we suggest the method of flipped learning can solve the problem of innovations in education.

The researchers argue that 'because of its new model and because it brought a new atmosphere in teaching and learning, the flipped classrooms began to be applied by many 
teachers and lecturers worldwide' (Halili \& Zainuddin, 2015, p. 15). Arslan, A. (2020) revealed that the USA, Malaysia, Jamaica, Hong Kong, Singapore, Somaliland, China, Taiwan, Australia, Canada, Saudi Arabia, and Turkey have the most publications on flipped learning. The author suggests that 'there is a notable scarcity of literature from Europe' (Arslan, 2020, p. 777). Unfortunately, Ukrainian researchers have done very few studies on flipped learning applications for teaching English as a foreign language. Insufficient research on the flipped classroom in professional foreign languages in Ukrainian universities has led to the choice of the research topic.

\section{Methods \\ Research Design}

This study mainly uses the descriptive-analytical method. To assess the effectiveness of flipped learning when teaching English, we provided quantitative and qualitative assessment control. The evaluation procedure involved the collection and analysis of direct and indirect results of the course learning. Immediate results of the course study were students' assessments at the end of the course and attendance indicators. Indirect learning results included students' attitudes, perceptions, and feelings towards the suggested course conditions, new opportunities revealed, creative development, possible problem-solving abilities, and critical thinking skills. We have evaluated the effect of studying this course on indirect results by surveying students using a Likert-scale survey.

\section{Participants}

We conducted our research in the 2018/2019 and 2019/2020 academic years at the Department of Foreign Philology and Translation at Vinnytsia Institute of Trade and Economics of Kyiv National University of Trade and Economics (VITE KNUTE), Ukraine. A total of 23 teachers engaged in the study and answered open-ended and yes/no questions. The participants also were 48 students aged 17-18. At the time of research, they were in the first year of their study at the Institute. Among them $64.6 \%(n=31)$ were female and $35.4 \%(n=17)$ were male. We divided all the students into four subgroups, 12 students in each one. During two academic years, flipped learning was being actively implemented in the classes of 'English for Specific Purposes', which is an obligatory course at the first and second years of study.

The flipped learning method is efficiently applied by the teaching staff of the Department of Foreign Philology and Translation at Vinnytsia Institute of Trade and Economics of Kyiv National University of Trade and Economics (VITE KNUTE). Having got acquainted with the successful experience of applying the flipped learning method at the world's leading universities (including the results of the project "Erasmus + iFlip" (iFLIP Project, 2017), the teachers of VITE KNUTE have decided to explore possible opportunities of flipped learning in teaching foreign languages. Table one discloses the distribution of classroom activities and students' assignments they had to do. An introductory interview was held with the students of the experimental groups to announce and explain the purpose and objectives of the functional training conditions. Under these conditions, all the students worked with the same learning materials, and we held the same assessment control. 
Arab World English Journal (AWEJ) Volume 12. Number 4. December 2021

Table 1. Classroom and online activities of the course 'English for Specific Purposes'.

\begin{tabular}{|l|l|}
\hline Classroom activities & Online activities \\
\hline $\begin{array}{l}\text { Communicative tasks to develop speaking and } \\
\text { writing skills }\end{array}$ & Lecture materials for the study \\
\hline Brainstorming activities & Vocabulary online training exercises \\
\hline Debates & Grammar online training exercises \\
\hline Team project work & Forum discussions in Moodle system \\
\hline Peer assessment of the projects done & Listening practice \\
\hline Consultations & Peer-review discussions \\
\hline Discussions of problems & Written feedback \\
\cline { 2 - 2 } & Online tests \\
\hline Grammar explanations & Quizzes \\
\hline
\end{tabular}

\section{Research Instruments}

In the context of reforming modern education, the student-oriented approach is one of the essential features in applying the method of flipped learning. This fact predetermined the research instruments chosen. Since the research instruments are tied to the study methodology, we had structured and unstructured interviews, observations, tests, and surveys. Non-directive discussions followed the interviewing as we expected some spontaneous decisions.

We prepared a survey-based online questionnaire to collect data and do our research in the Moodle platform in order to evaluate the flipped learning challenges during online learning. The survey-based questionnaire contained 15 multiple questions (multiple-choice, yes/no, and open-ended questions) covering research goals. It was designed using Moodle platform technical apps and distributed among students at the end of the semester. Afterwards we checked validity and reliability of the questionnaire.

\section{Research Procedures}

Within our research, we chose to begin with interviewing teachers with the vital question, 'Are you familiar with flipped learning?' Possible answers to this question were: 1. I have already applied this method. 2. I know what it is, and I know how to apply it. 3. I know what it is, but I don't know how to apply it. 4. I have heard about this method, but I know nothing about it. 5. I don't know what it is. The results of the pre-research survey showed that $22 \%$ of teachers of the Department have already used the flipped learning method in their practice, and another $52 \%$ did not have such an experience but showed a willingness to implement this method ('I know what it is and how to apply it'). Thus, $77 \%$ of the surveyed teachers were ready and, at the time of the survey (2018), had the opportunity to work using flipped learning. All 23 teachers of the Department were to some extent familiar with the flipped learning method. While interviewing teaching staff, all of them expressed anxiety because of possible barriers provided by flipped learning. The flipped learning method works well when there no technical problems: University should provide Internet access, quick hyperlinks to training materials, video, and audio also work correctly. Students also need basic knowledge in information and communication technologies in order to use online materials. Any technical problem can negatively affect motivation and the learning experience.

A necessary condition for applying the method of flipped learning is the adjusted work of a Learning Management System (LMS). According to the research results, there is a high 
relationship between the students' performance and implementation of digital educational resources from the e-learning platform (Rakic, Tasic, Marjanovic, Softic, Lüftenegger, \& Turcin, 2020). LMS creates a single database of e-courses and learning materials and manages the courses and students' activity (Ivanytska, Tymoshchuk, Dovhan, Osaulchyk, \& Havryliuk, 2021).

All e-courses taught in VITE KNUTE are created in LMS based on the online platform MOODLE. Each e-course contains a work program, syllabus, guidelines for studying the discipline and independent work of applicants, teaching materials for lectures and practical classes, and other necessary information. Using the MOODLE platform allows performing input, current, and output control of students' knowledge quickly. Our previous long-term experience of applying LMS based on the online platform MOODLE will enable to adapt the flipped learning method and remove barriers to its perception and application (Table two).

Table 2. Barriers to the application of the flipped learning method in the process of teaching English and assessment of the degree of their removal in VITE KNUTE.

\begin{tabular}{|l|l|l|}
\hline \multicolumn{1}{|c|}{ Removed barriers } & \multicolumn{1}{|c|}{ Partially removed barriers } & \multicolumn{1}{|c|}{ Barriers to be removed } \\
\hline $\begin{array}{l}\text { Changes and complications in forms of } \\
\text { control and knowledge assessment }\end{array}$ & $\begin{array}{l}\text { The high complexity of preparation } \\
\text { of educational materials }\end{array}$ & $\begin{array}{l}\text { The motivation of applicants to } \\
\text { watch videos and perform tasks }\end{array}$ \\
\hline $\begin{array}{l}\text { The unwillingness of teachers to } \\
\text { implement the method }\end{array}$ & $\begin{array}{l}\text { The need for thorough preparation } \\
\text { of group tasks and criteria for their } \\
\text { assessment }\end{array}$ & $\begin{array}{l}\text { The reluctance of students for } \\
\text { independent analysis of new } \\
\text { material }\end{array}$ \\
\hline $\begin{array}{l}\text { Changing the usual role of the teacher } \\
\text { to the role of a 'facilitator' }\end{array}$ & \begin{tabular}{l} 
then \\
\hline
\end{tabular}
\end{tabular}

While applying the method of flipped learning by the Department of Foreign Philology and Translation of VITE KNUTE, there were no technical barriers revealed, thus, we could prepare the best teaching materials giving students an excellent opportunity to work on it beforehand. The barriers partially removed include some limitations connected with the teacher's responsibilities. These barriers, such as the high complexity of teaching materials and the need for thorough preparation of group tasks and criteria for their assessment, were partially removed by teachers during the initial stage.

\section{Results}

The evaluation results of the of quantitative indicators while applying the method of flipped learning in teaching the course 'English for Specific Purposes' are shown in Figure one.

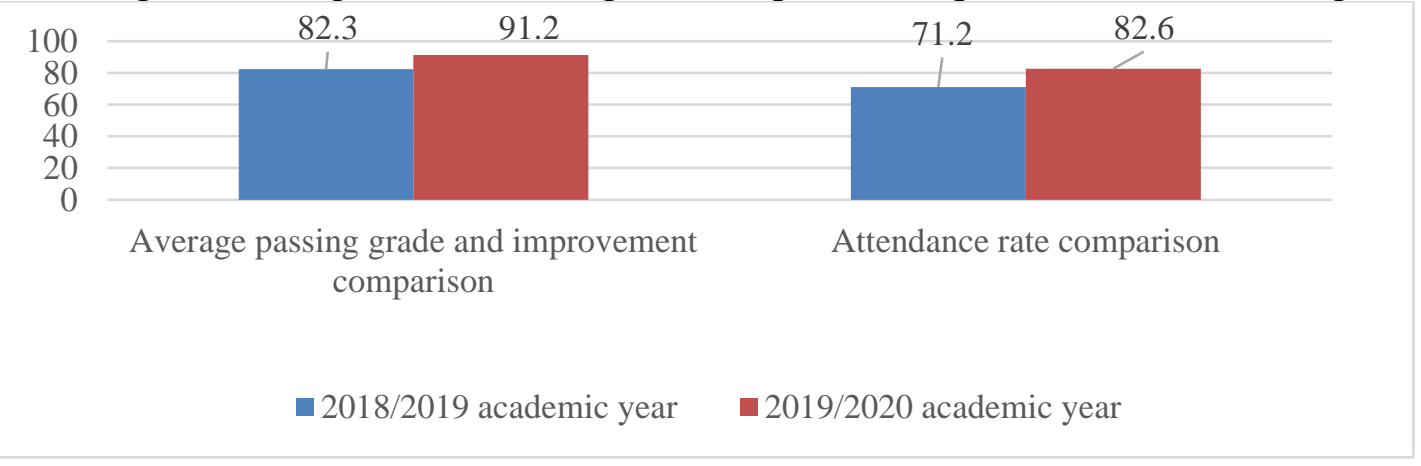

Figure 1. Average passing grade and attendance rate comparison ( $=48), \%$ 
Figure one presents the middle passing grade and improvement compared to the attendance rate during two academic years.

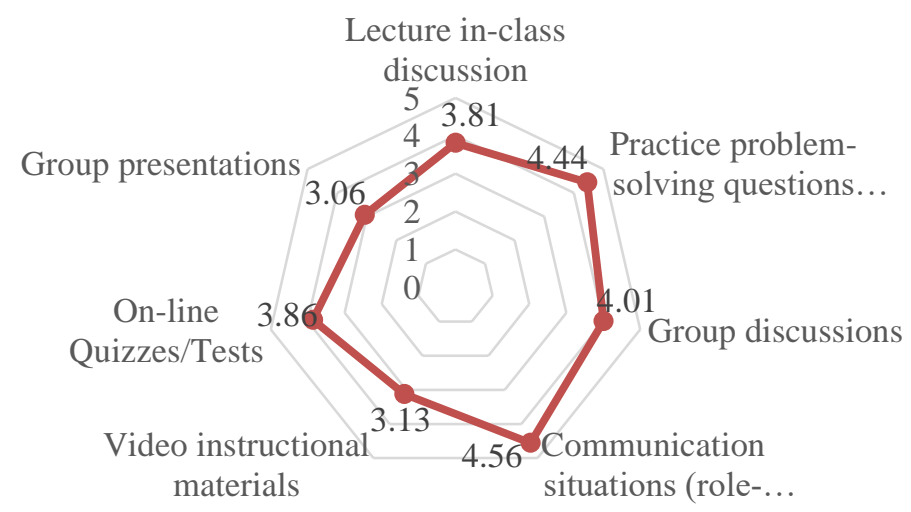

Figure 2. Opinion of the students on the efficiency of the flipped learning method within the course 'English for Specific Purposes' $(n=48)$, points $(1=$ very ineffective to $5=$ very effective)

The evaluation results showed that the average passing grade in the 2019/2020 academic year increased by $8.9 \%$ compared to the results of the $2018 / 2019$ academic year. The study also shows an increase in attendance rate by $11.4 \%$ in the $2019 / 2020$ academic year compared to the same period in the 2018/2019 academic year. According to the survey conducted at the end of the course, the level of positive perception and far going opportunities in the future reaches 9095\% (Figure two). The Likert-scale survey asked the students to rate the effectiveness of different elements of the flipped classroom. The students rated aspects on a scale of one to five (1=very ineffective, $2=$ =somewhat ineffective, $3=$ =neither effective, nor ineffective, 4=somewhat effective, and 5=very adequate). The results of assessing the students' satisfaction with the elements of flipped learning in teaching the course 'English for Specific Purposes' are shown in Figure three.

The lecturer encouraged my interest in the course

I like that flipped classroom offers more.

Feedback on assignments and/or in-course tests.

Online components helped improve my learning

"Flipped classroom" helped me to develop my.

The content of the course satisfies my professional.

"Flipped classroom" encouraged my interest to the.

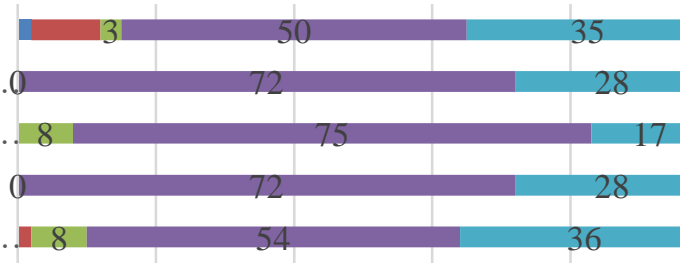

$$
\text { - Strongly disagree } \square \text { Disagree } \quad \text { Neutral }{ }^{20} \text { Agree }{ }^{40} \text { Strongly } 10 \text { agree } 80 \quad 100
$$

Figure 3. Survey results on the students' satisfaction with the course 'English for Specific Purposes' $(\mathrm{n}=48), \%$ 
According to the results of our research, most students agree that online components helped in improving the learning process (100\%). We noted as well that flipped classrooms offered more interaction with peers and the teacher $(100 \%)$, encouraged interest in the course (97\%), students truly define the content of the course productive for professional needs (96\%). They consider the feedback on assignments and in-course tests to be helpful (92\%) and this method to be helpful in developing personal autonomy and independence (90\%). 85\% of students agree the lecturer encouraged their interest in the course.

\section{Discussion}

Our research aim was to find out whether flipped learning is efficient enough within its implementation in teaching English. The presented study demonstrates that students got satisfied with flipped learning and characterize it as an effective educational environment for learners. Its practical applying activated the main characteristics of flipped learning, namely flexibility, individualization, differentiation, opportunities for students to learn at any place or time. Thus, students became more motivated and independent, responsible and self-confident, having improved language learning performance. These results coincide with those obtained in similar studies by Abdullah, Hussin \& Kemboja (2021). They also agree with Thoo, Hang, Lee, \& Tan (2021), who proved flipped classrooms enhance anxiety of learners in English speaking performance. The research conclusions align with Webb \& Doman (2016), in the part it leads to increased gains on learning outcomes and enhances cooperation and task orientation between teachers and students, according to Strayer (2012). Within flipped classrooms, we have distinguished three possible roles of teachers in the learnings process, as a facilitator, an instructor, and a resource, while the roles of the learners were as recipients and as partners, according to Mahalli, Nurkamto, Mujiyanto, \& Yuliasri (2019). Thus, we have revealed no severe facts to prove flipped learning inefficiency.

Instead, in the present study, we have found out possible problematic issues both for teachers (the complexity in preparing e-learning materials, the need for thorough preparation of tasks and criteria for assessment) and students (low motivation, weak readiness to independent work). The given results reveal the close connection between the efficiency of the flipped learning method and the preparatory period for flipped classrooms conducted by teaching staff. During the initial transition period it is necessary to get much work done: to revise the curriculum and divide the available teaching material, transfer some resources to vodcasts, and leave the rest for the classroom activities. While applying the flipped learning, university teachers have to review or prepare new group tasks, processes of control, and criteria for assessing students' work done. As our experience shows, teachers can remove these barriers within one-two year of the initial transition period of the method implementation.

To the group of limitations that must be overcome while applying flipped learning in VITE KNUTE, we also include some barriers connected with motivation, self-motivation, and willingness of students to work independently. These possible problems mainly relate to the degree of responsibility of students and are typical for applying the vast majority of other student-oriented methods in teaching foreign languages. 


\section{Conclusion}

The performed study has revealed that the flipped learning method can be successfully implemented into the innovative teaching of foreign languages to University students as a type of blended learning. Considering the current requirements of the modern education system, a new role of the teacher-facilitator makes this method highly effective under conditions of online learning. This model achieves success due to its flexibility, individualization of the educational process, and full focus on the student-oriented approach. This teaching method promotes the active development of speech skills and individual qualities and increases their academic performance. The research data indicate that the flipped learning method increased autonomy of the students, made them more motivated and responsible for their learning outcomes, and formed necessary hard and soft skills. Flipped classrooms offered more interaction between peers and the teacher, providing successful feedback on assignments and in-course tests, while the suggested online resources were well-adjusted and helpful. It became possible due to a wellorganized LMS with a single database of e-courses and learning materials available to the students.

We recommended to organize workshops and seminars for the teachers to gain skills for the adequate implementation of this method. The researchers also suggest carrying out further studies to find out what students' foreign language skills, namely writing, speaking, reading, or listening, can be formed more effectively under this method.

\section{About the Authors \\ Natalia Ivanytska, Doctor of Philology, Professor, Head of the Department of Foreign Philology and Translation of Vinnytsia Institute of Trade and Economics of Kyiv National University of Trade and Economics. Her academic interest is in the field of philology, social communication, and e-learning. https://orcid.org/0000-0002-9925-1285}

Larysa Dovhan is a Candidate of Pedagogical Sciences, Associate Professor. She teaches English for Specific Purposes, English for Professional Purposes, and Professional Communication in English. Scientific interests are as follows: innovative teaching methods and practices, e-learning, blended learning. https://orcid.org/0000-0003-4742-6570

Nataliia Tymoshchuk is a Candidate of Sciences (Philology), Associate Professor. Her main teaching courses are English for Professional Purposes, Professional Communication in English. Scientific interests are innovations in education, e-learning, mind-mapping, flipped classroom, methodology of teaching foreign languages, blended learning. https://orcid.org/0000-0001-56385825

Olga Osaulchyk is a Candidate of Sciences (Pedagogy), Associate Professor, is a teacher of foreign languages (English and German). Scientific interests: innovations in education, creative potential development, mindmapping, flipped classrooms, methodology of teaching foreign languages. https://orcid.org/0000-0003-4933-0652

Natalia Havryliuk is Candidate of Pedagogical Sciences, Associate Professor. Her professional orientation is mostly connected with monitoring projective techniques in teaching English, comparative pedagogy, theory and practice of translation, innovative technologies and methods of teaching English, e-learning, distance learning. https://orcid.org/0000-0002-6031-7777 


\section{References}

Abdullah, M. Y., Hussin, S., \& Kemboja, I. (2021). Does Flipped Classroom Model Affect EFL Learners' Anxiety in English Speaking Performance? International Journal of Emerging Technologies in Learning, 16(1), 94-108. http:/doi.org/10.3991/ijet.v16i01.16955

Abdullah, M. Y., Hussin, S., \& Ismail, K. (2019). Implementation of flipped classroom model and its effectiveness on English speaking performance. International Journal of $\begin{array}{lllll}\text { Emerging Technologies in Learning (IJET), } & 130 .\end{array}$ https://doi.org/10.3991/ijet.v14i09.10348

Afrilyasanti, R., Cahyono, B. Y., \& Astuti, U. P. (2017). Indonesian EFL students' perceptions on the implementation of flipped classroom model. Journal of Language Teaching and Research, 8(3), 476. https://doi.org/10.17507/jltr.0803.05

Al-Harbi, S.S, \& Alshumaimeri, Y. A. (2016). The Flipped Classroom Impact in Grammar Class on EFL Saudi Secondary School Students' Performances and Attitudes. English Language Teaching, 9(10), 60-80. http://dx.doi.org/10.5539/elt.v9n10p60

Arslan, A. (2020). A systematic review on flipped learning in teaching English as a foreign or second language. Journal of Language and Linguistic Studies, 16(2), 775-797. http://doi.org/ 10.17263/jlls.759300

Bane, J. (2014). Flipped By Design: Flipping the Classroom Through Instructional Design. Ohio: The Ohio State University.

Basal, A. (2015). The Implementation of a Flipped Classroom in Foreign Language Teaching. Turkish Education Online Journal of Distance -TOJDE, 16(4), 28-37. https://doi.org/10.17718/tojde.72185

Bergmann, J., \& Sams, A. (2012). Flip your Classroom: Reach Every Student in Every Class Every Day Jonathan. International Society for Technology in Education. Washington DC: International Society for Technology in Education World.

Bezzazi, R. (2019). Learning English Grammar Through Flipped Learning. The Asian Journal of Applied Linguistics, 6, 170-184.

Chatta, B. S., \& Haque, M. I. (2020). Improving Paragraph Writing Skills of Saudi EFL University Students Using Flipped Classroom Instruction. Arab World English Journal (AWEJ). Special Issue on CALL, 6, 228- 247. https://dx.doi.org/10.24093/awej/call6.15

Chen, Y., Wang, Y., \& Chen, N. S. (2014). Is FLIP enough? Or should we use the FLIPPED $\begin{array}{lllll}\text { model instead? Computers \& } \quad \text { Education, } & \text { 79, }\end{array}$ https://doi.org/10.1016/j.compedu.2014.07.004

Choe, E., \& Seong, M. H. (2016). A Case Study of the Flipped Classroom in a Korean University General English Course. Journal of Pan-Pacific Association of Applied Linguistics, 20(2), 71-93.

Hamdani, M. (2019). Effectiveness of Flipped Classroom (FC) Method on the Development of English language learning of the high School Students in Ahwaz. International Journal of Applied Linguistics \& English Literature, 8(2), 12-20.

iFLIP Project (2017). Adult Learners Needs Analysis Report. Survey Results and Conclusions. Retrieved from http://projectiflip.eu/wp-content/uploads/2018/05/ifLIP_IO2_AdultLearners-needs-analysis-report.pdf

Ivanytska, N., Tymoshchuk, N., Dovhan, L., Osaulchyk, O., \& Havryliuk, N. (2021). Effectiveness of digital resources in the learning management system within online education of future entrepreneurs. Journal of Entrepreneurship Education, 24(4). 1-8. Retrieved from: https://www.abacademies.org/articles/effectiveness-of-digital-resources- 
in-the-learning-management-system-within-online-education-of-future-entrepreneurs10533.html

Konoplianyk, L., \& Melnykova, K. (2019). Application of the "flipped classroom" technology when teaching a professional foreign language. Bulletin of the National Aviation University. Series: Pedagogy. Psychology, 2(15), 38-45.

Li, H., \& Zhang, Y. (2016). Application of Flipped Classroom in Medical Oral English Teaching. Eighth International Conference on Measuring Technology and Mechatronics Automation (ICMTMA), 11-12 March, 105-108. https://doi.org/10.1109/ICMTMA.2016.34

Mahalli, Nurkamto J., Mujiyanto, J. \& Yuliasri, I. (2019). The Implementation of Station Rotation and Flipped Classroom Models of Blended Learning in EFL. Learning. English Language Teaching, 12(12), 23-29. DOI:10.5539/elt.v12n12p23

Qader, R.O., \& Arslan, F.Y. (2019). The Effect of Flipped Classroom Instruction in Writing: A Case Study with Iraqi EFL Learners. Teaching English with Technology, 19(1), 36-55.

Rajesh, M. (2015). Revolution in communication technologies: impact on distance education. Turkish Online Journal of Distance Education-TOJDE, 16(1), 62-88.

Rakic, S., Tasic, N, Marjanovic, U., Softic, S., Lüftenegger, E. \& Turcin, I. (2020). Student Performance on an E-Learning Platform: Mixed Method Approach. International Journal of Emerging Technologies in Learning (iJET). 15(2), 187-203. DOI:10.3991/ijet.v15i02.11646

Saitta, E., Morrison, B., Waldrop, J., \& Bowdon, M. (2016). Introduction: Joining the Flipped Classroom Conversation. In J. Waldrop, \& M. Bowdon (Eds.). Best Practices for Flipping the College Classroom (pp. 1-16). New York: Routledge.

Santikarn, B., \& Wichadee, S., (2018). Flipping the Classroom for English Language Learners: A Study of Learning Performance and Perceptions. iJET. 13(9), 123-135.

Strayer, J. (2012). How learning in an inverted classroom influences cooperation, innovation and task orientation. Learning Environments Research, 15(2), 171-193. Doi:10.1007/s10984-012-9108-4

Thaichay, T., \& Sitthitikul, P. (2016). Effects of the flipped classroom instruction on language accuracy and learning environment: A case study of Thai EFL upper-secondary school students. Rangsit Journal of Educational Studies, 3(2), 35-64.

Thoo, A. C., Hang, S. P., Lee, Y. L., \& Tan, L. C. (2021). Students' Satisfaction Using ELearning as a Supplementary Tool. International Journal of Emerging Technologies in Learning, 16(15), 16-31. https://doi.org/10.3991/ijet.v16i15.23925

Webb, M., \& Doman, E. (2016). Does the Flipped Classroom Lead to Increased Gains on Learning Outcomes in ESL/EFL Contexts. CATESOL Journal, 28(1), 39-67.

Wu, W.C. V., Chen, H. J. S., \& Yang, J. C. (2017). Creating an Online Learning Community in a Flipped Classroom to Enhance EFL Learners' Oral Proficiency. Educational Technology \& Society, 20(2), 142-157.

$\mathrm{Yu}, \mathrm{Z}$. \& Wang, G. (2016). Academic Achievements and Satisfaction of the Clicker-Aided Flipped Business English Writing Class. Educational Technology \& Society, 19(2), 298312. 